\title{
PRO KONTRA ZAKAT MUSTAGHALLAH
}

\author{
Oleh: \\ Irdlon Sahil ${ }^{1}$ \\ Email: irdlonsahil88@gmail.com
}

\begin{abstract}
Mustaghallah is something that is leased like gold and silver jewelry whose levels do not reach two hundred dirhams, rice fields, land, and so on. Mustaghallah is something that benefits continue to grow and produce but the goods do not disappear or run out. The group of fuqaha is' modern, mustaghallah are assets which are not classified as the type of al-amwal alzakawiyah (assets which are obliged to zakat) which are not used for personal or trade purposes but can generate large income either by renting them out or sell their products. The majority of traditional ulama and some contemporary scholars argue that mustaghallah is not compulsory for zakat, their reason being that there are no shari'ah statements in the Shari'ah texts which explain their zakat obligations. While the majority of contemporary scholars and some traditional ulama argue that mustaghallah is obligatory for zakat, their reason is that the obligation of zakat is contained in mustaghallah even though there is no text explaining shari'ah, because the law will appear together with the existence of god.
\end{abstract}

Key words: zakat, mustaghallah, figh

\section{Pendahuluan}

Islam adalah agama yang memberikan rahmat kepada seluruh alam. agama yang sangat memperhatikan terhadap nasib kaum duafa', fuqara, dan masakin, tak heran jika syariatnya banyak mengajarkan kepada para pemeluknya peka terhadap masyarakat di sekitarnya terutama mereka yang hidup di bawah garis kemiskinan.

Salah satu syariah Islam adalah kewajiban zakat mal bagi orangorang kaya yang telah dianugerahkan kelebihan harta. Nilai-nilai yang terkandung di dalamnya mengajarkan kita supaya suka berbagi rezki yang telah diberikan Allah Swt terhadap kita kepada fakir miskin. Orang yang menunaikan kewajiban zakat disamping melaksanakan ibadah yang

${ }^{1}$ Dosen Prodi Pendidikan Bahasa Arab STAI Syaichona Moh. Cholil Bangkalan 
telah diperintahkan oleh Allah Swt di dalamnya juga terkandung nilai sosial yang sangat tinggi yang dapat mensucikan hati dan jiwa orang yang melaksanakannya sehingga menjadi pribadi yang dermawan serta suka membantu kepada orang-orang membutuhkan uluran tangannya.

Zakat mal hanya diwajibkan kepada aghniya (orang-orang kaya) yang hasil usahanya sudah mencapai nishab, baik dari jenis-jenis harta zakat yang berjumlah enam yang telah disepakati oleh para ulama, seperti emas dan perak, usaha pertanian makanan pokok, perkebunan buah-buahan, serta industri perdagangan dan lain sebagainya atau jenis harta yang masih diperselisihkan di antara ulama tentang kewajiban zakatnya, seperti: zakat perhiasan batu-batu mulia, zamrud, mutiara, dan lain-lain, termasuk juga mustaghallah.

Mustaghallah adalah jenis harta yang masih diperselisihkan kewajiban zakatnya, namun ia dapat memberikan income yang sangat besar kepada pemiliknya seperti halnya industri perdagangan, namun ia tidak sama dengan perdagangan, karena perdagangan adalah jual beli barang atau tukar menukar barang dengan tujuan mencari keuntungan. Berbeda dengan mustaghallah, kalau dalam mustaghallah keuntungan diperoleh dari manfaatnya bukan dari penjualan barangnya seperti jasa persewaan hotel, transpostasi, dan sebagainya.

\section{Makna Zakat}

Kata zakat secara etimologi dari asal kata زكايزكو زكاة yang mempunyai arti tumbuh dan berkembang. ${ }^{2}$ Ali bin Abi Thalib berkata: harta akan berkurang karena dinafkahkan, beda dengan ilmu yang akan selalu bertambah dan berkembang dengan diamalkan". ${ }^{3}$

Kata zakat selain secara bahasa memiliki arti tumbuh dan berkembang, ia juga mempunyai beberapa makna yang lain di antaranya: a. Bermakna الصلاح (kebaikan). Allah Swt berfirman dalam Surat alMu'minun: ayat 4:

${ }^{2}$ Ibrahim Musthafa, Ahmad Hasan Ziyat dkk, al-Mu'jam al-Wasit, Majma' alLughah al-Arabiyyah, al-Maktabah al-Islamiyah,Juz:I, hlm 396, Istanbul: Turki.

${ }^{3}$ Al-Mandhur,Ibnu, Lisan al-Arab Hal: 64 Juz 6, Dar Ihya' al-Turats al-Arabi, dan Muassasah al-Tarikh al-Rarabi, Beirut, Libanon. 


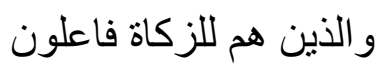

Artinya: dan orang-orang yang mengerjakan zakat

Menurut sebagin ulama kata "zakat" bermakna العمل الصالح (amal kebaikan). Dalam ayat lain Allah Swt berfirman dalam Surat al-Kahfi, ayat 8:

خير ا منه زكاة

Artinya: lebih baik darinya zakatnya (amal kabaikannya)

Menurut sebagian ulama kata zakat bermakna amal kabaikannya ${ }^{4}$

b. Bermakan المدح (pujian). Allah Swt berfirman dalam surat al-Najm ayat 32:

Artinya: jangan engkau puji diri kalian sendiri

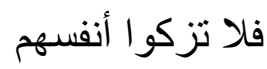

c. Bermakna كثير الخير (banyak kebaikannya), seperti perkataan orang arab: "إيركة الكان زاك". Orang itu bnyak kebaikannya.

d. Bermakna البركة : زكت النفقة: Seperti perkataan orang Arab: nahkahya diberi keberkahan ${ }^{5}$.

Menurut al-Nawawi kelebihan harta yang dikeluarkan oleh syariat diberi nama zakat karena ia akan melipat gandakan harta pokoknya dan akan menjaganya dari afat ${ }^{6}$. Senada dengan pendapat al-Nawawi, alSarkhasi juga mengatakan: bertambahnya harta itu dengan cara Allah Swt. Akan menggantinya dengan yang lebih banyak di dunia dan akan memberi pahala di akhirat kepada orang yang mengeluarkan7. Firman Allah Swt dalam surat al-Nisa' ayat 39:

$$
\text { وما أنفقتم من خير فهو يخلفه }
$$

Artinya: apa yang kalian nafkahkan dari kebaikan maka Allah Swt akan menggantinya.

${ }^{4}$ Ibid, hlm: 64-65.

${ }^{55}$ Ibrahim Musthafa, Ahmad Hasan Ziyat dkk, al-Mu'jam al-Wasit, Majma' alLughah al-Arabiyyah, al-maktabah al-Islamiyah,Juz:I, hlm 396, Istanbul: Turki.

6 Al-Nawawi, al-Majmu', Juz V, hlm: 295.

${ }^{7}$ Al-Mabsut, Juz II, Hal: 149, Dar al-Kutub al-Ilmiyah, Beirut, Libanon. 
Makna zakat secara syara' ada beberapa perbedaan di antara ulama. Ulama Ahnaf atau kelompok Hanafiyah mendefinisikan zakat dengan, menyerahkan sebagian harta yang ditentukan oleh syara' kepada fakir miskin yang muslim yang bukan keturunan Bani Hasyim dan juga bukan hamba sahayanya semata-mata karena Allah Swt.

Golongan Malikiyah mendefinisikan zakat secara syara': mengeluarkan sebagian tertentu dari harta tertentu yang sudah mencapai nishab jika kepemilikan sudah sempurna kecuali harta tambang dan sawah $^{8}$. Menurut Syafi'iyah, zakat adalah nama bagi sesuatu tertentu yang diambil dari harta tertentu dan dari golongan tertentu yang diberikan kepada kelompok tertentu9.

Ulama Hanabilah memberikan definisi yang sangat sederhana terhadap zakat. Menurut mereka, zakat adalah hak yang wajib dikeluarkan dari harta tertentu10. Sedangkan kelompok Syiah Zaidiyah mendefinisikan zakat, mengeluarkan sebagain dari harta dengan niat zakat dengan jalan tertentu secara perkiraan bukan secara pasti11.

Dari beberpa definisi zakat di atas dapat disimpulkan bahwa pengertian zakat secara syara' ialah sebuah perkerjaan mengeluarkan atau melaksanakan kewajiban pada harta yang dimiliki oleh seseorang kepada kelompok tertentu.

Kata zakat dalam syariat terkadang juga diungkapkan dengan bahasa shadaqah yang maksudnya adalah zakat, bukan shadaqah sunnah. Seperti firman Allah Swt dalam Surat al-Taubah ayat 103:

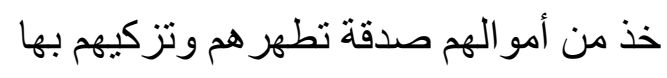

Artinya: ambillah dari harta-harta mereka sadaqah (zakat) untuk mensucikan dan membersihkan mereka

Dan Surat al-Taubah ayat: 60:

8 'Ulaisy, Muhammad, Minah al-Jalil 'ala Syarh Khalil, Juz I, hlm 322, Dar Shadir

9 Al-Nawawi, al-Majmu' Juz 5, hlm 295.

${ }^{10}$ Qudamah, Ibnu, al-Mughni, Dar al-Kutub al-Ilmiyah, bairut, Libanon.

${ }^{11}$ Al-Murtadla, Ahmad bin Yahya, Dar al-Hikam al-Yamaniyah, San'a, Yaman. 
انما الصدقات للفقر اء و المساكين

Artinya: bahwasanya sadakah-sadakah (zakat-zakat) itu wajib diberikan kepada orang-orang fakir dan orang-orang miskin.

Seperti juga banyak disebutkan dalam hadits-hadits Nabi Saw kata zakat dsisebutkan dengan kata shadaqah.

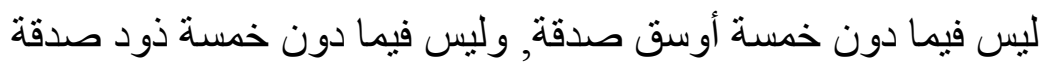

Artinya: biji-bijian yang kurang dari lima ausuq tidak wajib shadaqah (zakat), dan unta yang belum mencapai lima ekor tidak wajib shadaqah.

Hadits Nabi Saw:

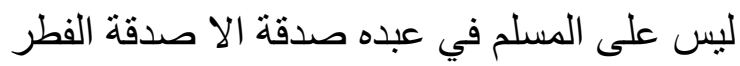

Artinya: bagi seorang muslim pada budak sahayanya tidak ada shdaqah (zakat) kecuali shadaqah fitri (zakat fitri).

Oleh karena itu, banyak di antara para fuqaha dalam karya-karyanya menulis dengan bab Shadaqah al-Zar'i, seperti al-Syafi'i dalam karya monumentalnya, al-Umm, atau bab Shadaqah al-Fithri seperti Abi Muhammad Muhmud al-Aini dari kalangan Ahnaf, seperti juga alSyaukani dalam karya-karya fikihnya.

Menurut Ibnu Muhammad Mahmud al-Aini, kolerasi antara zakat dengan shadaqah, karena makna shadaqah secara bahasa berasal dari kata sidqu, yang berarti benar atau jujur supaya menunjukkan kebenaran atau kejujuran seorang hamba dalam ubudiyyah ketika menunaikan zakat ${ }^{12}$.

\section{Jenis-jenis Harta yang Wajib Zakat}

Mayoritas ulama sepakat bahwa ada enam jenis harta yang wajib dikeluarkan zakatnya jika sudah mencapai syarat-syarat tertertu, yakni

${ }^{12}$ Al-Binayah fi Syarh Hidayah, Juz III, Hal: 339, Dar Fikr, Beirut, Libanon. 
haul dan nishab, tidak ada perselisihan di antara para fuqaha' baik golongan Ahnaf, Malikiyah, Syafi'iyah dan Hanabilah bahwa harta yang wajib dizakati sebanyak enam jenis, yaitu:

1. Emas dan perak;

2. Tanaman biji-bijian (makanan pokok seperti beras, gandum, dan lainlain), buah-buahan (anggur dan kurma);

3. Hewan ternak (unta, sapi, dan kambing);

4. Ma'adin (Tambang emas dan perak);

5. Rikaz (emas dan perak peninggalan zaman dahulu);

6. Harta dagangan ${ }^{13}$.

Kecuali kelompok kecil seperti al-dhahiriyah dan al-Syaukani yang mengatakan tijarah (harta dagangan) tidak wajib zakat ${ }^{14}$.

Namun demikian ada beberapa harta yang masih menjadi perdebatan di kalangan ulama tentang kewajiban zakatnya, di antaranya ialah:

1. Sayur-sayuran

2. Madu

3. Kuda

4. Tambang selain emas dan perak seperti tembaga, timah, minyak, dan lain-lain.

5. Perhiasan batu-batu mulia seperti yakut, mutiara, dan lain-lain ${ }^{15}$

6. Profesi.

7. Mustaghallah atau penghasilan.

${ }^{13}$ Al-hanafi, Ibnu Humam, Fath al-Qadir Syarh al-Hidayah, Juz III, hlm 610, alDasuqi, Muhammad bin arafah, Hasyiyah al-Dasuqi, Juz II, Hal: 3, Dar Kutub al-Ilmiyah, Beirut, Libanon, al-Khatib al-Syarbini, Muhammad Ibn, Mughni al-Muhtaj, Juz I, hlm 500, Dar Fikr, Beirut, Libanon, al-Hanbali, Abi Ishaq Burahnuddin, al-Mabda' fi Syarh alMaqna', al-Maktab al-Islami, Beirut, Libanon.

${ }^{14}$ Al-Andalusi, Ibn Hazm, al-Muhalla, Juz IV, hlm 12, Dar Fikr Beirut, Libanon, al-Syaukani, Muhammad Ali, al-Darari al-Mudliyyah Syarh Durar al-bahiyyah, Juz I, Hal: 348, Maktabah al-Irsyad, San'a, Yaman.

${ }^{15}$ Rusyd, Ibnu, Bidayah al-Mujtahid Nihayah al-Muqtashid, hlm: 286, Cet.I, Th 2003, Muassasah al-Risalah Nasyirun, Beirut, Libanon, al-Nawawi, al-Majmu', Juz II, Hal: 145, al-Dardir, Ahmad bin Muhammad, al-Syarh al-Shaghir Ala Aqrab al-Masalik ila Madhab al-Imam malik, Juz I, hlm 589, Cet. I, Th, 1410 H, Wazarah al-adl, wa al-Syu'un al-Islamiyah wa al-ayuqaf, Daulah al-Imarat al-Arabiyah al-Muttahidah, Qudamah, Ibnu, al-Mughni, Juz Ii, Hal:491, al-Murtadla, al-Bahr al-Zakhkhar, Juz II, hlm 145. 


\section{Zakat al-Mustaghallah (Penghasilan)}

Sebelum lebih jauh membahas tentang zakat mustaghallah, ada baik terlebih dahulu kita mambahas tentang pengertian المال (harta) baik secara bahasa ataupun secara istilah fuqaha', karena al-mustaghallah atau penghasilan termasuk bagian dari maal atau harta itu sendiri.

Secara bahasa kata المال, berarti sesuatu yang dimiliki oleh individu atau golongan seperti harta dagangan, pekarangan, ladang, perhiasan, uang, hewan ternak, dan sebagainya ${ }^{16}$.

Menurut Ibnu al-Atsir, maal atau harta pada dasarnya sesuatu yang dimiliki oleh seseorang berupa emas dan perak kemudian kata maal digunakan pada makna yang lebih luas untuk segala sesuatu yang dimiliki berupa harta benda yang lain seperti: sawah, ladang rumah, hewan ternak, dan sebagainya. Kata maal ketika diungkapkan dikalangan orang Arab zaman dulu diartikan onta, karena mayoritas harta benda yang dimiliki mereka adalah onta ${ }^{17}$.

Al-Zarkashi, mendefinisikan maal dengan sesuatu yang disenangi yang dapat dinikmati ketika dibutuhkan ${ }^{18}$. Sebagian fuqaha' ada yang mendefinisikan secara lebih luas, sesuatu yang bermanfaat atau siap dimanfaatkan, baik berupa sesuatu yang konkrit kelihatan mata seperti: rumah, mobil, motor, sawah dan sebagainya atau sesuatu yang bersifat abstrak seperti manfaat atau jasa, contohnya seperti manfaat atau jasa pengiriman barang, jasa persewaan kendaraan, jasa tranportasi umum dan sebagainya ${ }^{19}$.

${ }^{16}$ Al-Mu'jam al-Wasit, Majma' al-Lughah al-Arabiyah, al-Idarah al-Ammah li alMajma'at wa Ihya al-Turats, Juz III, hlm 893.

${ }_{17}$ Al-Mandhur, Ibnu, Lisan al-Arab, Juz 13, hlm 223.

18 Al-Zarkashi, Badruddin Muhammad bin Bhadir, al-Mantsur fi al-Qawaid, Juz III, hlm 223, A'maal Mausu'iyyah Musa'adah, Wazarah al-Auqaf wa al-Shu'un alIslamiyah, Daulah Kuwait.

19 'Abin ,Ibnu, Radd al-Muhtar ila al-Durr al-Mukhtar, Juz IV, Hal:3, al-Qadlawi, Fiqh al-Zakah, Juz I, hlm: 142, Cet. II,Th.1424 H.2003 M., Maktabah Wahbah, Cairo, Mesir, Zaidan, Abd Karim, Madkhal ila Dirasah al-Islamiyah, hlm 183, Cet. XVI, Th. 2002, Muassasah al-Risalah, Bairut, Libanon. 
Kata mustaghallah berasal dari kata الغلة yang artinya الدخل (pendapatan) seperti hasil persewaan tanah, rumah atau villa, ongkos jasa angkutan umum, ongkos jasa pengiriman barang dan lain sebagainya ${ }^{20}$.

Ada dua kelompok ulama yang mendefinisikan mustaghallah secara terminologi kelompok ulama atau fuqaha' tradisional dan kelompok fuqaha' modern.

Dari kelompok fuqaha' tradisional seperti al-Nawawi - dari kalangan Syafi'iyah- dan al-Qadli Ahmad al-'Ansi - dari kalangan Syi'ah Zaidiyah mendefinisikan mustaghallah, setiap sesuatu yang disewakan seperti perhiasan emas dan perak yang kadarnya tidak mencapai dua ratus dirham, sawah, tanah dan sebagainya ${ }^{21}$.

Menurut Abi al-Hasan Abdullah bin Miftah, hakikat mustaghallah ialah sesuatu yang manfaatnya terus berkembang dan menghasilkan, akan tetapi barangnya tidak sirna atau habis'22.

Sedangkan kelompok fuqaha' modern, memberikan pengertian mustaghallah dengan definisi yang lebih luas. Menurut mereka, mustaghallah adalah harta-harta yang ia sendiri tidak tergolong jenis alamwal al-zakawiyah (harta-harta yang wajib zakat) yang tidak digunakan untuk kepentingan pribadi atau perdagangan akan tetapi dapat mendatangkan penghasilan yang besar baik dengan cara menyewakannya atau menjual hasil produksinya ${ }^{23}$.

Menurut Yusuf al-Qardlawi, mustaghallah adalah harta-harta yang dapat mendatangkan penghasilan atau keuntungan bagi pemiliknya ${ }^{24}$. Sedangkan menurut Ahmad Ali al-salus, mustghallah adalah: perusahan, tanah, sarana transportasi dan lain sebagainya yang bergerak di bidang

${ }^{20}$ Lisan al-Arab, Juz X,Hal: 110, Mu'jam al-Wasit, Juz II, hlm: 66.

21 Al-Taaj al-madzhab li Al-Madzhab, Juz I, hlm 193, Dar al-Hikam alYamaniyah, San'a, Yaman,

${ }^{22}$ Al-Muntaza' al-Mukhtar min al-Ghaits al-Midrar al-ma;ruf bi Syarh al-Azhar, Juz III, hlm: 319, Cet. I, th. 2003 M., Makatabah al-Turats alIslami, Sha'dah, Yaman.

${ }^{23}$ Muhammad Makki, Jum'ah, Zakat al-Amwal wa Kaifa Ada'uha fi al-Fiqh alIslami, hlm: 188, Dar al-Huda.

${ }^{24}$ Al-Fatawi al-Ma'ashirah, Juz III, hlm: 359, Cet II, Th. 2002, Dar al-Ilmi, alShafah, Kuwait. 
jasa manfaat yang dapat menghasilan keuntungan yang bukan bergerak dibidang perdagangan ${ }^{25}$.

Dari beberpa definisi di atas dapat dipahami bahwa mustaghallah adalah perusahaan-perusahaan yang bergerak di bidang jasa dan manfaat yang dapat mendatangkan income yang besar terhadap pemiliknya yang tidak berupa perdagangan, seperti: perusahaan perhotelan, perusahaan transportasi, peternakan, dan sebagianya.

\section{Hukum Zakat Mustaghallah}

Mayoritas ulama tradusional baik Ahnaf, Malikiyah, Syafi'iyah dan sebagin besar Hanabilah dan sebagian ulama modern berpendapat bahwa mustghallah tidak wajib zakat. Alasan mereka bahwa tidak ada nash syariat yang menyatakan atas kewajiban zakat mustaghallah, karena al-amwal alzakawiyah sudah ditentukan oleh syariat hanya ada enam jenis yaitu: emas dan perak, biji-bijian (makanan pokok seperti beras, gandum, dan lainlain), buah-buahan (anggur dan kurma), hewan ternak (unta, sapi dan kambing), ma'adin (tambang emas dan perak), rikaz (emas dan perak peninggalan zaman dahulu), dan harta dagangan ${ }^{26}$.

Dalil yang menunjukkan bahwa mustaghallah tidak wajib zakat ialah:

1. Hadits Riwayat dari Ali bin Abi Thalib ra.

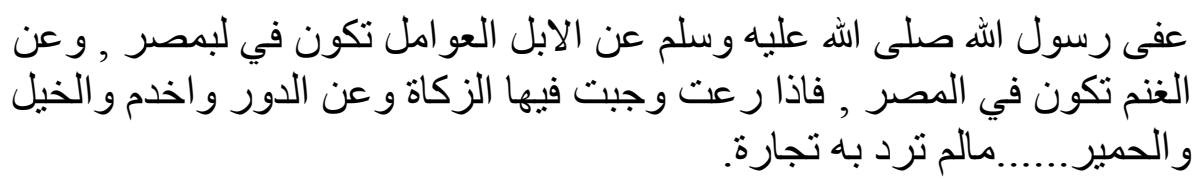

Artinya: Rasulullah Saw mengampuni -tidak mewajibkan zakat- pada onta di Mesir yang dipekerjakan, dan dari kambing di Mesir maka apabila hewan-hewan itu digembala maka wajib zakat, dan beliau tidak mewajibkan zakat juga pada rumah-rumah, budak-budak sahaya, kuda, himar, ....... kecuali dibuat perdagangan.

${ }^{25}$ Al-Mu'amalat al-Maliyah al-Mu'ashirah fi Mizan al-Fiqh al-Islami, hlm: 412.

${ }^{26}$ Al-'Ajzi, Ali bin Muhammad, hlm: 215, Dar al-Hikmah al-Yamaniyah, San'a, Yaman. 
2. Hadits Nabi Saw

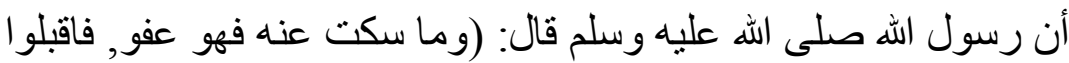

$$
\begin{aligned}
& \text { عافيته, فان الهه لم يكن ليتس شيئا) , وتلا : (وما ربك لك نسيا). }
\end{aligned}
$$

Artinya :Sesuatau yang oleh Allah Swt dan Rasul-Nya Saw, didiamkan tidak diwajibkan- maka itu berarti diampuni -tidak diwajibkan zaktanya-, maka terimalah pengampunanan-Nya, karena tidak mungkin melupakan sesuatu" kemudian beliau mambaca ayat: "dan tidaklah Tuhannu itu lupa".

Dari kedua hadits di atas dapat dipahami bahwa sesuatu yang oleh syariat diampuni artinya tidak dijelaskan maka hal itu menunjukkan tidak wajib zakat. Maka mustaghallah termasuk sesuatu yang didiamkan atau diampuni oleh syariat tentang kewajiban zaktanya maka hal itu menunjukkan bahwa mustaghallah tidak wajib zakat.

3. Haditsh:

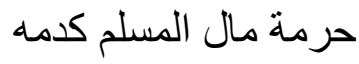

Artinya: kehormatan harta seorang muslim sama posisinya seperti kehormatan darahnya.

4. Hadits:

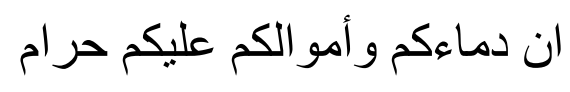

Artinya: sesungguhnya darah-darah kalian dan harta-harta kalian dimulyakan.

Dari kedua hadits tersebut dapat dipahami bahwa tidak boleh mewajibkan zakat pada harta seorang muslim jika tidak ada keterangan dalam nash al-Qur'an ataupun Hadits Nabi Saw yang menjelaskan tentang kewajibannya. Dalam hal ini al-Syaukani berkata: "sesungguhnya harta-harta umat Islam dilindungi dengan perlindungan agama Islam, maka tidak boleh mengambilnya kecuali 
dengan alasan yang dibenarkan oleh syariat, jika hal itu dilakukan maka akan termasuk memakan harta orang lain dengan cara yang batil" 27 .

5. Hadits:

$$
\text { ليس على المسلم صدقة في عبده و لا في فرسه }
$$

Artinya: tidak ada kewajiban zakat bagi seorang muslim pada budak sahaya dan kunya.

6. Dalil Logika

Menurut kelompok ini bahwa harta zakat sudah ditentukan jenis dan jumlahnya yaitu ada enam seperti yang sudah dijelaskan di atas, dan mustghallah tidak dimasukkan dalam jenis itu. Ini menunjukkan bahwa mustaghallah tidak wajib zakat. Hukum asal menunjukkan bahwa seorang muslim tidak mempunyai kewajiban mangeluarkan zakat pada hartanya terkecuali ada nash dari syariat yang sharih (jelas) menerangkan hal itu28.

Sebagian ulama tradisional dari kalangan Hanabilah seperti Abu alWafa' bin 'Aqil29 dan ulama al-Hadawiyah -pecahan golongan Syiah alZaidiyah-, dan mayoritas ulama modern seperti: Abu Zahrah, Khallaf, Abdurrahman Hasan, Yusuf al-Qardlawi, Wahbah al-Zuhaili, Ali Ahmad Salus dan lain-lainya berpendapat bahwa mustaghallah wajib zakat ${ }^{30}$. Pendapat mereka didasarkan pada beberapa dalil:

1. Al-Qur'an

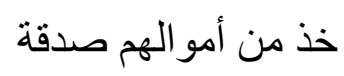

Artinya: ambillah dari harta mereka zakatnya.

Dari ayat ini dapat disimpulkan bahwa Allah Swt memerintahkan untuk mengambil zakat dari harta kaum muslimin. Ayat tersebut masih bersifat umum, jadi semua harta yang wajib zakat diperintahkan untuk

${ }^{27}$ Al-Sail al-jarrar alMudfiq ala Hadaiq al-Azhar, Juz Ii, hlm 27, Dar Kutub alIlmiyah, Beirut, Libanon.

${ }^{28}$ Al-Qardlawi, Yusuf, Fiqh al-zakah, Juz I, hlm: 491.

${ }^{29}$ Al-Jauziyah, Ibnu Qayyum, Bada'I al-Fawaid, Juz III, hlm: 143, Dar al-Fikr, Beirut, Libanon., al-'Ajri,Ali bin Muhammad, al-Maqasid al-Shalihah, fi al-Fatawa alWadlihah, hlm: 315.

${ }^{30}$ Fiqh al-Zakah, Juz I, hlm: 492, al-Zuhaili, Wahbah, Fiqh al-Islami wa adillatuh, Juz II, hlm: 864, al-Salus, Ali Ahmad, al-Mu'amalat al-Maliyah al-Mu'ashirah fi Mizan alFiqh al-Islami, hlm: 412. 
diambil termasuk juga mustaghallah, kecuali ada ayat atau keterangan dari hadits yang mengkhususkannya ${ }^{31}$.

2. Hadits Rasulullah Saw ketika mengutus Muadz bin Jabal ke negeri Yaman, beliau berkata:

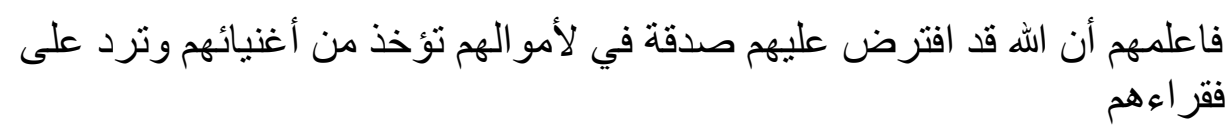

Artinya: umumkanlah kepada mereka bahwa Allah Swt. Sungguh telah mewajibkan zakat pada harta-harta mereka yang diambil dari orang-orang kaya mereka dan dibagikan kepada orang-orang fakir mereka.

Dari hadits di atas dapat disimpulkan bahwa Nabi Saw memerintahkan Muadz bin Jabal untuk mengambil zakat dari harta orang kaya untuk dibagikan kepada orang-orang fakir di negeri Yaman, tidak menutup kemungkinan juga termasuk kekayaan yang dihasilkan dari mustaghallah karena termasuk kekayaan yang dimiki oleh orang-orang kaya pada saat itu.

\section{Dalil Qiyas}

Ulama yang mewajibkan zakat mustaghallah mereka menguatkan pendapatnya dengan mengqiyaskan zakat mustaghallah dengan harta tijarah (perdagangan), menurut mereka, ada kesamaan antara mustaghallah dengan harta tijarah, dari segi sama-sama menghasilakn keuntungan dengan cara mengelola harta ${ }^{32}$.

4. Dalil logika

a. Para fuqaha' sepakat bahwa illah (alasan) diwajibkannya zakat pada harta ialah النماء' (berkembang) yang bersifat ta'aqquli (bersifat lagika) artinya, ketentuan jenis-jenis harta zakawiyah yang telah ditentukan oleh syariat bukan harga mati artinya bukan hnya saja enam jenis, bisa jadi karena perkembangan zaman akan bertambah seiring dengan kemajuan zaman dan munculnya persoalan-

${ }^{31}$ Abd Salam, Abi Yahya, al-Jawahir al-Mudliyyah Syarh Nikat al- Ibadat, hlm: 130, Cet. II, th. 1994, Maktabah al-Yaman al-Kubra, San'a, Yaman.

${ }^{32}$ Al-Maqasihid al-Syariah, hlm: 2016-2017. 
persoalan sosial dimasyarakat, lebih-lebih di zaman modern ini dimana mustaghallah dapat mendatangkan penghasilan yang sangat besar bagi pemiliknya, sedangkan hukum akan selalu berkembang dan berubah mengikuti perubahan illah (alasan)-nya33.

b. Bahwa hikmah disyariatkannya zakat ialah untuk membersihkan dan mensucikan harta dan diri pemilik harta itu sendiri serta untuk membantu meringankan beban ekonomi orang-orang fakir dan miskin dan bahkan pada awal pemerintahan Islam menjadi salah satu income yang sangat besar bagi kas negara untuk kepentingan penyebaran agama Islam, oleh karena itu maka mewajibkan zakat pada mustaghallah lebih ihtiyath (kehati-hatian) dari pada menghukumi tidak wajib34.

\section{Simpulan}

Dari paparan di atas dapat disimpulakan beberapa kesimpulan antara lain:

1. Mustaghallah adalah harta kekayaan atau penghasilan yang didapat dari pengelolaan jasa persewaan seperti: villa, hotel, transportasi baik udara seperti perusahaan maskapai penerbangan, perusahaan taxi, jasa transportasi umum seperti: bus, atau penghasilan dari pengelolaan hasil produksi seperti perusahaan peternakan ayam petelor, perternakan sapi, lebah dan lain sebagainya yang tidak bergerak dibidang perdagangan.

2. Terjadi prokontra di antara ulama mengenai kewajiban zakat mustaghallah. Mayoritas ulama tradisional dan sebagian ulama modern menghukumi tidak wajib zakat yang didasarkan pada dalil-dalil alQur'an dan Hadits yang intinya mengatakan tidak didapatkan keterangan yang sharih (jelas) tentang keawajiban zakat mustaghallah, oleh kerena itu hukumnya tidak wajib zakat. Karena harta umat Islam itu suatu kemuliaan seperti hanya darah mereka yang tidak boleh diambil dengan alasan zakat jika tidak ada keterangan yang jelas dari syariat.

${ }^{33}$ Zakat al-Amwaal wa Kaifa Ada'iha, Hal: 192, Fiqhal_Zakah, Juz I,Hal:493.

${ }^{34}$ Fiqh al-Zakah, Juz I, hlm: 493. 
3. Sebaliknya mayoritas ulama kontemporer dan sebagian ulama tradisional justru mewajibkan zakat pada mustaghallah. Mereka juga melandaskan pada dalil-dali al-Qur'an, Hadits, Qiyas dan dalil ma'qul (logika) hujjah mereka ialah bahwa mustaghallah termasuk harta kekayaan yang income-nya sangat besar kepada pemiliknya, sesuatu yang belum disebutkan di dalam syariat secara sharih belum tentu tidak ada hukumnya, karena illah atau alasan kewajiban zakat pada harta yaitu al-namaa' (berkembang) yang termasuk ma'qulah al-ma'na - masih ada ruang untuk berubah- bukan ta'abbudi - yang sudah harga mati dari syariat dan tidak bias ditawar lagi- oleh karena itu harta-harta yang wajib zakat bisa bertambah tidak terpaku pada enam jenis di atas, di samping itu hikmah kewajiban zakat adalah untuk mensucikan dan membersihkan jiwa dan harta pemiliknya dan untuk menbantu meringankan beban ekonomi fakir miskin, sedangkan faktanya para pemilik perusahaan-perusahaan itu sangat besar jadi yang lebih ihthiyath (hati-hati) mewajibkan zakat bagi para pemilik mustaghallah itu.

Dari kesimpulan di atas penulis lebih cenderung kepada pendapat ulama yang mewajibkan zakat mustaghallah sebab beberapa alasan:

1. Agama Islam sangat peduli dan perhatin terhadap kesejahteraan umat Islam terutama kaum fuqara dan masakin, oleh karena itu zakat diwajibkan bagi golongan orang kaya, supaya ada pemerataan dan tidak terjadi kesenjangan sosial di tengah-tengah masyarakat.

2. Bahwa pelaku bisnis yang bergerak di bidang jasa dan manfaat seperti perusahaan jasa persewaan hotel, villa, transportasi dengan segala jenisnya merupakan perusahaan yang sangat besar. Penghasilan yang dipeoroleh juga sangat besar bahkan bisa melebihi industri perdagangan, jika karena alasan tidak ada nas yang sharih kemudian tidak diwajibkan zakat maka orang-orang kaya akan semakin kaya sementara kaum du'afa, fuqara, dan masakin akan semakin misikin karena sebagin dari harta orang-orang kaya tidak tersalurkan kepada mereka.

3. Bahwa hukum itu akan berubah seiring perubahan illah, karena perkembangan dan tuntutan zaman. Oleh karenanya yang lebih relefan ialah menghukumi wajib zakat pada mustaghallah. 


\section{DAFTAR PUSTAKA}

Abin, Ibnu. Radd al-Muhtar ila al-Durr al-Mukhtar.

Al-Andalusi, Ibn Hazm. al-Muhalla. Dar Fikr Beirut, Lebanon.

Al-'Ajri, Ali bin Muhammad, al-Maqasid al-Shalihah, fi al-Fatawa al-Wadlihah.

Al-'Ajzi, Ali bin Muhammad, Dar al-Hikmah al-Yamaniyah, San'a, Yaman.

Al-Binayah fi Syarh Hidayah, Dar Fikr, Bairut, Libanon.

Al-Fatawi al-Ma'ashirah, Cet II, Th. 2002, Dar al-Ilmi, al-Shafah, Kuwait.

Al-Hanafi, Ibnu Humam. Fath al-Qadir Syarh al-Hidayah. al-Dasuqi, Muhammad bin Arafah, Hasyiyah al-Dasuqi. Dar kutub al-Ilmiyah, Beirut, Libanon.

Al-Hanbali, Abi Ishaq Burahnuddin,. al-mabda' fi Syarh al-maqna'. alMaktab al-Islami. Beirut, Libanon.

Al-Jauziyah, Ibnu Qayyum, Bada'I al-Fawaid, Dar al-Fikr, Beirut, Lebanon.

Al-Khatib al-Syarbini, Muhammad Ibn. Mughni al-Muhtaj. Dar Fikr, Beirut. Libanon,.

Al-Mabsut. Dar al-Kutub al-Ilmiyah, Beirut, Libanon.

Al-Mandhur, Ibnu. Lisan al-Arab. Dar Ihya' al-turats al-Arabi, dan Muassasah al-Tarikh al-Rarabi. Bairut, Libanon.

Al-Mu'amalat al-maliyah al-Mu'ashirah fi Mizan al-Figh al-Islami.

Al-Mu'jam al-Wasit, Majma' al-Lughah al-arabiyah, al-Idarah al-Ammah li alMajma' at wa Ihya al-Turats.

Al-Muntaza' al-Mukhtar min al-Ghaits al-Midrar al-ma;ruf bi Syarh al-azhar, Cet. I, th. 2003 M, Maktabah al-Turats allslami, Sha'dah, Yaman. 
Al-Murtadla, Ahmad bin Yahya, Dar al-Hikam al-Yamaniyah, San'a, Yaman.

Al-Nawawi. al-Majmu' al-Dardir,

Al-Qadlawi. Figh al-Zakah. Cet. II,Th.1424 H.2003 M. Maktabah Wahbah, Kairo, Mesir.

Al-Sail al-Jarrar, al-Mudfiq ala Hadaiq al-Azhar, Dar Kutub al-Ilmiyah, Beirut, Lebanon.

Al-Salus, Ali Ahmad, al-Mu'amalat al-Maliyah al-Mu'ashirah fi Mizan al-Figh al-Islami.

Al-Syaukani, Muhammad Ali, al-Darari. al-Mudliyyah Syarh Durar albahiyyah. Maktabah al-Irsyad, San'a, Yaman.

Al-Taaj al-madzhab li Al-Madzhab, Dar al-Hikam al-Yamaniyah, San'a, Yaman.

Al-Zarkashi, Badruddin Muhammad bin Bhadir, al-Mantsur fi al-qawaid, A'maal mausu'iyyah Musa'adah, Wazarah al-auqaf wa al-Shu'un al-Islamiyah, Daulah Kuwait.

Al-Zuhaili, Wahbah. Figh al-Zakah, Figh al-Islami a Adillatuh,

Ibnu, al-Mughni, Juz Ii, Hal:491, al-Murtadla, al-Bahr al-Zakhkhar.

Ibrahim Musthafa, Ahmad Hasan Ziyat, dkk. al-Mu'jam al-Wasit, majma' alLughah al-arabiyyah. al-Maktabah al-Islamiyah. Istanbul: Turki.

Jum'ah, Muhammad Makki. Zakat al-amwal wa kaifa Ada'uha fi al-Figh alIslami, Dar al-Huda.

Muhammad, Ahmad bin. 1410 H. al-Syarh al-Shaghir Ala Aqrab al-Masalik ila Madhab al-Imam malik, Cet. I, Th, 1410 H,

Rusyd, Ibnu. 2003. Bidayah al-Mujtahid Nihayah al-Muqtashid, Cet.I. Muassasah al-Risalah Nasyirun. Beirut, Lebanon. 
Salam, Abd \& Abi Yahya. 1994. al-Jawahir al-Mudliyyah Syarh Nikat al'Ibadat. Maktabah al-Yaman al-Kubra, San'a, Yaman.

Qudamah, Ibnu. al-Mughni. Dar al-Kutub al-Ilmiyah, bairut, Libanon.

Ulaisy, Muhammad. Minah al-Jalil 'ala Syarh Khalil, Juz I, Hal: 322. Dar Shadir

Wazarah al-Adl, wa al-Syu'un al-Islamiyah wa al-Auqaf, Daulah al-Imarat al-Arabiyah al-Muttahidah. Qudamah.

Zaidan, Abd Karim, Madkhal ila Dirasah al-Islamiyah, Cet. XVI, Th. 2002. Muassasah al-Risalah, Bairut, Lebanon. 
Jurnal Pendidikan dan Pranata Islam 